\title{
Serum vitamin $D$ levels in treatment-naïve chronic hepatitis B patients
}

\author{
Ebada Said ${ }^{1}$, Waleed El Agawy², Rehab Ahmed², Mohamed Hassany², \\ Amal Ahmed ${ }^{3}$, Hanan Fouad ${ }^{4}$, Hosam Baiumy ${ }^{1}$ \\ 'Department of Hepatology, Gastroenterology and Infectious Diseases, \\ Benha Faculty of Medicine, Benha University, Banha, Egypt \\ ${ }^{2}$ Tropical Medicine Department, National Hepatology \& Tropical Medicine Research Institute (NHTMRI), \\ Cairo, Egypt; \\ ${ }^{3}$ Department of Biochemistry and Molecular Biology, National Hepatology and Tropical Medicine Research \\ Institute (NHTMRI), Cairo, Egypt; \\ ${ }^{4}$ Department of Internal Medicine, El Kanater General Hospital, Al Qalyubia, Egypt
}

\section{ABSTRACT}

Background and Objectives: According to the demographic health survey conducted in 2015 , Egypt had $10 \%$ documented prevalence of anti-HBc positive patients aged $1-59$ and $1 \%$ viremic patients amongst the population in the same age group, with a domination of genotype D. Several studies claimed the possible role of vitamin D deficiency in hepatitis B virus (HBV) replication and disease progression. Patients and Methods: Serum vitamin D levels [25(OH) D3] were assessed in $96 \mathrm{HBeAg}$ negative non-cirrhotic chronic HBV patients and 25 healthy subjects classified as following: Group I: 48 chronic HBV patients with persistently normal ALT levels and HBV DNA level $<2000 \mathrm{IU} / \mathrm{mL}$ for $\geq 6$ months; Group II: 48 chronic HBV patients with $\mathrm{CHB}$ with persistently elevated ALT and HBV DNA level $\geq 2000 \mathrm{IU} / \mathrm{mL}$ for $\geq 6$ months; and Group III: 25 apparently healthy subjects with normal liver enzymes and negative hepatitis viral markers were taken as the control group. Results: Vitamin D was much more deficient in group II than in group I and group III being $11.55 \pm 3.97 \mathrm{ng} / \mathrm{mL}, 15.03 \pm 3.45,27.00 \pm 6.76 \mathrm{ng} / \mathrm{mL}$ $(P<0.001)$, respectively, and a strong negative correlation was observed between vitamin $\mathrm{D}$ levels and HBV DNA levels $(P=0.043)$ in groups I and II. Conclusion: The current study showed high HBV DNA replication in patients with vitamin $D$ deficiency suggesting the antimicrobial immunomodulatory role of vitamin $\mathrm{D}$.

Key words: Egyptian, hepatitis B virus, vitamin D

\section{INTRODUCTION}

Address for Correspondence: Dr. Mohamed Hassany, Tropical Medicine Department, National Hepatology \& Tropical Medicine Research Institute (NHTMRI), P.O. 11441, 10 Kasr Al Aini Street, Cairo, Egypt

Email: mohamadhassany@yahoo.com

\begin{tabular}{|l|}
\hline Access this article online \\
\hline $\begin{array}{l}\text { Website: } \\
\text { www.intern-med.com }\end{array}$ \\
\hline $\begin{array}{l}\text { DOI: } \\
\text { 10.1515/jtim-2017-0038 }\end{array}$ \\
\hline Quick Response Code: \\
\hline \\
\\
\\
\\
\end{tabular}

Egypt has one of the highest burdens of viral hepatitis globally. In 2015, a demographic health survey (DHS) documented the prevalence of anti-HBc in $10 \%$ of the Egyptian population between the age group 1-59 years, with slight male predominance and great variation in age distribution (less than 1\% among children aged 1-14 years, $43 \%$ among adults aged $55-59$ years). In this survey, the patients with active hepatitis B virus (HBV) infection and positive viremia represent $1 \%$ of the population in the same age group ${ }^{[1]}$ Genotype $\mathrm{D}$ is the major infecting genotype in Egypt representing more than $85 \%$ of those with chronic $\mathrm{HBV}^{[2]}$
The liver is a major site for vitamin D synthesis, where 25-hydroxylation occurs, and a large portion vitamin $\mathrm{D}$ binding protein is manufactured. Due to its immunomodulatory role, there is growing evidence about the interrelationship between vitamin $\mathrm{D}$ and different chronic liver diseases in different stages. ${ }^{[3]}$ Different studies have shown a wide, universal agreement of vitamin $\mathrm{D}$ deficiency in patients with chronic hepatitis $\mathrm{C}$ virus (HCV) infection, ${ }^{[4,5]}$ chronic HBV, ${ }^{[6,7]}$ nonalcoholic steatohepatitis $(\mathrm{NASH})^{[8]}$ and hepatocellular carcinoma (HCC) ${ }^{[9]}$ with contradictory reports about the impact of vitamin D deficiency on disease pathology and progression. 
Although most countries in Africa are sunny throughout the year, but still vitamin $\mathrm{D}$ deficiency is a major problem in most African countries, ${ }^{[10]}$ particularly Egypt, which suffers from this problem in both diseased ${ }^{[1]}$ and healthy people. ${ }^{[12,13]}$.

The current study was designed to assess the serum levels of vitamin D [25(OH) D3] in the treatment naïve chronic HBV patients and its impact on the disease status.

\section{PATIENTS AND METHODS}

The study was reviewed and approved by an independent ethics committee and conducted in accordance with the declaration of Helsinki and good clinical practice guidelines. All authors had access to the study data, and they reviewed and approved the final manuscript. All enrolled patients provided written, informed consent prior to the start of the study. It was a prospective study in which 121 subjects were enrolled between July 2015 and February 2016. A total of $96 \mathrm{HBeAg}$ negative chronic HBV patients and 25 healthy subjects were recruited and sub-classified into 3 groups: Group I: 48 chronic HBV patients with persistently normal ALT level and HBV DNA level $<2000 \mathrm{IU} / \mathrm{mL}$ for $\geq 6$ months; Group II: 48 chronic HBV patients with $\mathrm{CHB}$ with persistently elevated ALT and HBV DNA level $\geq 2000$ $\mathrm{IU} / \mathrm{mL}$ for $\geq 6$ months; Group III: 25 apparently healthy subjects with normal liver enzymes and negative hepatitis viral markers were taken as the control group.

\section{Inclusion criteria}

Adults of both genders $\geq 18$ years old with proven chronic $\mathrm{HBV}$ infection (defined as HBsAg+ and Positive HBV DNA PCR [polymerase chain reaction] for $\geq 6$ months) were included. All included patients were HBV genotype D.

\section{Exclusion criteria}

1.Co-infection with HCV, hepatitis D virus (HDV), and human immunodeficiency virus (HIV);

2. Advanced liver fibrosis (fibroscan $\geq 12.5 \mathrm{kPa}$, liver biopsy $\geq$ F3 by Metavir score)

3. HCC or decompensated liver cirrhosis;

4. Those who were receiving medications known to affect vitamin D3 level or metabolism (calcium, vitamin D supplementation, oestrogen, alendronate, isonicotinic acid hydrazine [INH], Thiazide diuretics, long-term antacids, calcium channel blockers, cholestyramine, anticonvulsants, orlistat);

5. Renal, or parathyroid disease;

6. Chronic intestinal disease.

\section{Laboratory investigations}

We performed laboratory study as detailed below:

1. Full routine laboratory investigations;
2.HBV DNA measurement by real time PCR (Roche): Serum HBV-DNA was measured by use of COBAS AmpliPrep/COBAS TaqMan with detection limit of 12 $\mathrm{IU} / \mathrm{mL}$. HBV-DNA levels were expressed in $\mathrm{IU} / \mathrm{mL}$; 3. Serum vitamin D level [25(OH)D3]: by using enzymelinked immunosorbent assay (ELISA) kit, we measured serum $25(\mathrm{OH})$ vitamin $\mathrm{D}$, the most stable circulating form of this molecule using DRG Assay quantitative determination of 25-OH Vitamin D in plasma and serum (DRG International Inc., USA);

4. To avoid seasonal variations of vitamin $\mathrm{D}$ level, the blood samples of the whole study populations were withdrawn in the same month (February 2016).

\section{Statistical analysis}

The collected data were tabulated and analysed using SPSS version 16 software (Spss Inc, Chicago, ILL Company) and MedCalc software. Categorical data were presented as number and percentages while quantitative data were expressed as mean \pm standard deviation, median and range. Chi square test $\left(\chi^{2}\right)$, or Fisher's exact test (FET) were used to analyse categorical variables. Quantitative data were tested for normality using Kolmogorov-Smirnov test, using Student ' $t$ and if normally distributed, or Mann Whitney $U$ test, Kruskal Wallis test and Spearman's correlation coefficient (rho) if not normally distributed. The accepted level of significance in this work was stated at 0.05 $(P<0.05$ was considered significant $)$.

\section{RESULTS}

In the current study, the patients' enrolment and categorization was done on the basis of follow up of liver enzymes (once in 3 months) and HBV viral load (once in 3 months); the patients with normal ALT levels and $\mathrm{HBV}$ viral load $<2000 \mathrm{IU} / \mathrm{mL}$ in 2 consequent visits were allocated to group I of the study, while those with elevated ALT and HBV viral load $\geq 2000 \mathrm{IU} / \mathrm{mL}$ in 2 consequent visits were allocated to group II. The patients with fluctuating ALT levels or viral load were not included in the trial. All enrolled patients were treatment naïve and had a negative history of receiving any specific antiviral drugs before inclusion in the study. The results of vitamin $\mathrm{D}$ level assay were interpreted as deficiency level $(<20 \mathrm{ng} / \mathrm{mL})$, insufficiency level $(20-30 \mathrm{ng} / \mathrm{mL})$ and normal level $(>30 \mathrm{ng} / \mathrm{mL})^{[14]}$. The 3 groups had similar values for age, $B M I$ and sex distribution with significant higher levels of AST, ALT, AFP and HBV DNA and lower levels of albumin were observed in group II compared to other groups $(P<0.001)$, as shown in Table 1 .

Table 2 describes the noticed levels of vitamin D insufficiency in the control group compared to the clear deficiency noticed in both study groups (I, II) cumulatively 
with $(P<0.001)$, or even separately as in Table 3, Figure 1 which showed a descending level of vitamin $\mathrm{D}$ for the control group (III) followed by the inactive chronic HBV group (I), then the lowest level in the active chronic HBV group (II) $(P<0.001)$.

Table 4, Figures 2, 3 showed a strong negative correlation between vitamin $\mathrm{D}$ levels and the degree of $\mathrm{HBV}$ viremia, the high DNA replication occurs in those with more deficient vitamin D levels and vice versa in groups I, II $(P=0.043, P<0.001)$ respectively. Positive correlation between BMI and vitamin D levels was noticed in group I, II $(P=0.024, P<0.001)$ respectively. Also, a positive correlation was noticed in group II between vitamin $\mathrm{D}$ levels with albumin and platelet count $(P=0.015, P=$ 0.002) respectively.

\section{DISCUSSION}

The influence of vitamin $\mathrm{D}$ deficiency on augmentation of many chronic liver diseases had reached to a near evidence. Many clinical trials and meta-analyses have strongly linked vitamin $\mathrm{D}$ deficiency with liver fibrosis progression, regardless the aetiology of chronic liver disease, with unclear causality relationship whether liver morbidity, affects vitamin D synthesis or the vitamin deficiency and is the contributor in the development of liver pathology. ${ }^{[15]}$

The current study tested the hypothesis of vitamin $\mathrm{D}$ deficiency and HBV replication in $96 \mathrm{HBeAg}$ negative non-cirrhotic chronic HBV patients; in this study, the nullification of many factors that could negatively implicate the harmony of the results was maximally done, like inclusion of patients without significant fibrosis, $\mathrm{HBeAg}$ negative, matched age and sex, vitamin D sample withdrawal in the same month, and so on.

Egypt has a problem of vitamin D deficiency that seems

\begin{tabular}{|c|c|c|c|c|}
\hline & $\begin{array}{l}\text { Group I } \\
(n=48)\end{array}$ & $\begin{array}{l}\text { Group II } \\
(n=48)\end{array}$ & $\begin{array}{l}\text { Group III } \\
(n=25)\end{array}$ & $P$ value \\
\hline Age (years) & $40.25 \pm 9.46$ & $38.22 \pm 9.64$ & $38.4 \pm 10.42$ & 0.58 \\
\hline Gender (males/females), $n(\%)$ & $30(62) / 18(38)$ & $31(64) / 17(36)$ & $15(60) / 10(40)$ & 0.45 \\
\hline BMI $\left(\mathrm{kg} / \mathrm{m}^{2}\right)$ & $30.55 \pm 4.63$ & $30.65 \pm 4.45$ & $28.8 \pm 3.12$ & 0.16 \\
\hline AST (IU/L) & $23.7 \pm 10.54$ & $43.7 \pm 22.4$ & $29.7 \pm 8.40$ & $<0.001$ \\
\hline ALT (IU/L) & $20.7 \pm 9.5$ & $53.1 \pm 27.68$ & $27.5 \pm 6.13$ & $<0.001$ \\
\hline Bilirubin $(\mathrm{mg} / \mathrm{dL})$ & $0.81 \pm 0.26$ & $0.79 \pm 0.27$ & $0.75 \pm 0.20$ & 0.69 \\
\hline Albumin $(\mathrm{g} / \mathrm{dL})$ & $4.34 \pm 0.33$ & $4.09 \pm 0.49$ & $4.49 \pm 0.46$ & $<0.001$ \\
\hline PT (s) & $13.2 \pm 0.83$ & $13.3 \pm 0.75$ & $13.0 \pm 0.75$ & 0.5 \\
\hline Haemoglobin $(\mathrm{g} / \mathrm{dL})$ & $13.4 \pm 2.03$ & $13.6 \pm 1.83$ & $12.7 \pm 1.06$ & 0.14 \\
\hline WBCs $\left(10^{9} / \mathrm{L}\right)$ & $5.92 \pm 1.66$ & $6.21 \pm 1.49$ & $6.74 \pm 1.88$ & 0.13 \\
\hline Platelets $\left(10^{9} / \mathrm{L}\right)$ & $210.4 \pm 56.61$ & $201.6 \pm 45.32$ & $226.2 \pm 83.35$ & 0.24 \\
\hline $\operatorname{AFP}(\mathrm{ng} / \mathrm{mL})$ & $2.88 \pm 01.31$ & $3.40 \pm 1.860$ & $1.21 \pm 1.03$ & $<0.001$ \\
\hline HBV DNA (IU/mL) & $673.98 \pm 572.27$ & $\begin{array}{l}2925103.8 \pm \\
14888722.3\end{array}$ & - & $<0.001$ \\
\hline
\end{tabular}

BMI: body mass index; ALT: alanine aminotransferase; AST: aspartate aminotransferase; PT: prothrombin time; WBCs: white blood cell counts; AFP: alpha-fetoprotein.

\begin{tabular}{lclc}
\hline \multicolumn{1}{l}{ Table 2: Comparison between serum vitamin D levels in the study groups (patients $v s$. control) } \\
\hline Group & $\boldsymbol{n}$ & Serum vitamin D $(\mathbf{n g} / \mathbf{m L})$ & $\boldsymbol{P}$ value \\
\cline { 2 - 3 } & & Mean \pm SD & $<0.001$ \\
\hline Patients (Group I, II) & 96 & $13.3 \pm 4.1$ \\
Control (Group III) & 25 & $27.00 \pm 6.76$ \\
\hline
\end{tabular}

\begin{tabular}{lcll}
\hline Table 3: Comparison between serum vitamin D levels in the 3 study groups & \\
\hline Groups & $n$ & Serum vitamin D $(\mathbf{n g} / \mathbf{m L})$ & $P$ value \\
& & Mean \pm SD & \\
\hline I & 48 & $15.03 \pm 3.45$ & $<.001$ \\
II & 48 & $11.55 \pm 3.97$ & \\
III & 25 & $27.00 \pm 6.76$ & \\
\hline
\end{tabular}




\begin{tabular}{|c|c|c|c|c|}
\hline \multirow{3}{*}{ Variables } & \multicolumn{4}{|c|}{ Serum Vitamin D } \\
\hline & \multicolumn{2}{|c|}{ Group I $(n=48)$} & \multicolumn{2}{|c|}{ Group II $(n=48)$} \\
\hline & $r$ & $P$ & $r$ & $P$ \\
\hline$\overline{\text { Age }}$ & -0.01 & 0.95 & 0.07 & 0.64 \\
\hline BMI & 0.326 & 0.024 & 0.497 & $<0.001$ \\
\hline ALT & -0.048 & 0.74 & -0.011 & 0.94 \\
\hline AST & -0.006 & 0.97 & -0.123 & 0.41 \\
\hline Total bilirubin & -0.046 & 0.75 & -0.276 & 0.058 \\
\hline Albumin & 0.131 & 0.37 & 0.350 & 0.015 \\
\hline INR & -0.112 & 0.45 & -0.265 & 0.07 \\
\hline Haemoglobin & 0.023 & 0.87 & 0.148 & 0.32 \\
\hline WBCs & 0.04 & 0.78 & 0.09 & 0.55 \\
\hline Platelets & 0.05 & 0.75 & 0.467 & 0.002 \\
\hline AFP & -0.091 & 0.54 & 0.217 & 0.14 \\
\hline HBV-DNA-PCR & -0.293 & 0.043 & -0.114 & $<0.001$ \\
\hline
\end{tabular}

BMI: body mass index; ALT: alanine aminotransferase; AST: aspartate aminotransferase; INR: international normalized ratio; WBCs: white blood cell counts; AFP: alpha-fetoprotein; PCR: polymerase chain reaction.

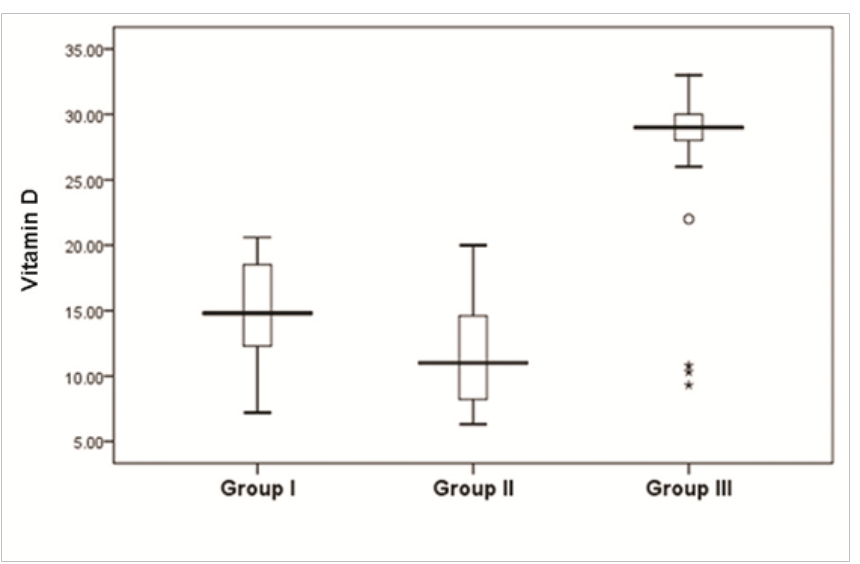

Figure 1: Serum vitamin D level in the 3 study groups

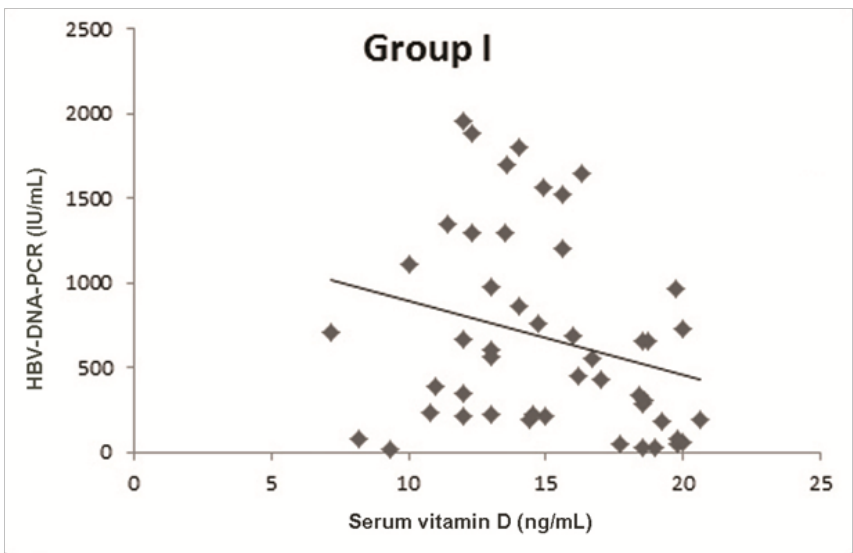

Figure 2: Correlation between serum vitamin D level and HBV-DNA-PCR in group I to be on a national base and may not be directly related to certain diseases. Many published data suggest multiple possible contributing factors, including dark skin colour, dietary calcium deficiency and inadequate sun exposure. ${ }^{[13]}$ The data explained the relatively low levels of vitamin D in the control group.

On the other hand, both chronic HBV groups (I, II) showed reduced levels compared to the control group. In group (I), which represented the inactive HBV disease, the level of vitamin D was significantly higher than group (II), which represented the active HBV infection, suggesting the immunomodulatory effect of vitamin $\mathrm{D}$ and its role

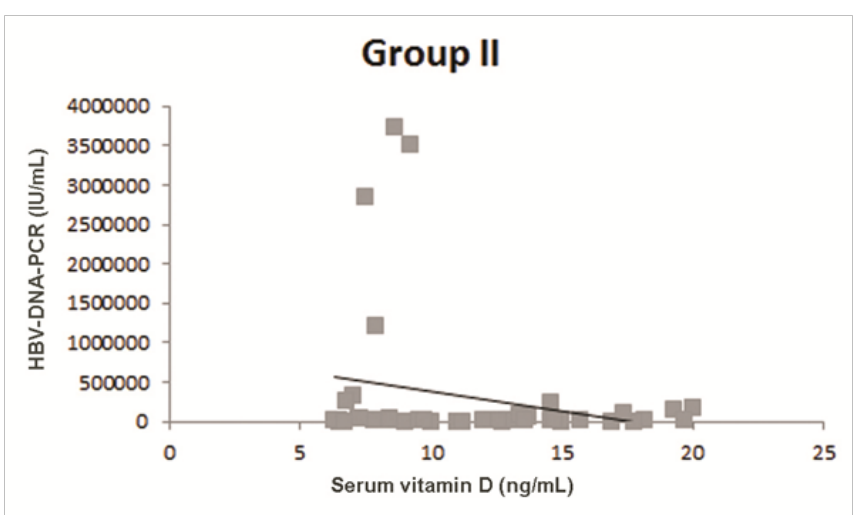

Figure 3: Correlation between serum vitamin D level and HBV-DNA-PCR in group II 
as anti-microbial agent. ${ }^{[6]}$ This could explain the high viral replication in group (II) compared to group (I) and its subsequent impact on the elevated AST, ALT and AFP levels and relatively reduced levels of albumin in group (II) compared to group (I). The absence of liver cirrhosis and other confounding factors in these groups confirms to a great extent the role of vitamin D in HBV replication and its ability to transform its status from an inactive to an active disease.

Our study observed the patients in only 2 stages of the disease: the inactive stage and the stage of chronic hepatitis. Yet, Hoan and his colleagues described more frequent vitamin $\mathrm{D}$ deficiency in post HBV cirrhotic patients and those with HBV related HCC than those with chronic active hepatitis. ${ }^{[16]}$ Patients with positive HBeAg were not included in this study, but few studies reported more reduction in vitamin D levels in patients with positive HBeAg than those who were negative. ${ }^{[7,17]}$

In our study, although vitamin D levels had a strong negative correlation with HBV DNA levels, yet it did not show any correlation with the degree of necroinflammation represented by AST, ALT levels, in contradiction to some studies. ${ }^{[17]}$ Yet the inflammatory changes in liver histology sometimes did not match with the level of liver enzymes .

In conclusion, the current study highlights the impact of vitamin D deficiency on $\mathrm{HBV}$ replication in particular, and its role in disease activity. Meanwhile, it is recommended to study vitamin D status in all HBV stages and to study the impact of vitamin D replacement and correction on the disease progression or regression in different stages.

\section{Conflict of Interest}

All authors report no conflicts of interest.

\section{REFERENCES}

1. Egypt Health Issues Survey 2015. Available from: https://dhsprogram. com/pubs/pdf/FR313/FR313.pdf

2. Khaled IAEA, Mahmoud OM, Saleh AF, Bioumie EE. Prevalence of HBV genotypes among Egyptian hepatitis patients. Mol Biol Rep 2011;38:4353-7.
3. Arteh J, Narra S, Nair S. Prevalence of vitamin D deficiency in chronic liver disease. Dig Dis Sci 2010;55:2624-8.

4. Ladero JM, Torrejon MJ, Sanchez-Pobre P, Suarez A, Cuenca F, de la Orden V, et al. Vitamin D deficiency and vitamin D therapy in chronic hepatitis C. Ann Hepatol 2013;12:199-204.

5. Esmat G, El Raziky M, Elsharkawy A, Sabry D, Hassany M, Ahmed A, et al. Impact of vitamin D supplementation on sustained virological response in chronic hepatitis $C$ genotype 4 patients treated by pegylated interferon/ribavirin. J Interf Cytokine Res 2015;35:49-54.

6. Demir C, Demir M. Vitamin D levels in patients with chronic hepatitis $B$ virus infection and naturally immunized individuals. Intern Med Insid 2013;1:4.

7. Farnik H, Bojunga J, Berger A, Allwinn R, Waidmann O, Kronenberger $\mathrm{B}$, et al. Low vitamin $\mathrm{D}$ serum concentration is associated with high levels of hepatitis B virus replication in chronically infected patients. Hepatology 2013;58:1270-6.

8. Nelson JE, Roth CL, Wilson LA, Yates KP, Aouizerat B, MorganStevenson V, et al. Vitamin D Deficiency Is Associated With Increased Risk of Non-alcoholic Steatohepatitis in Adults With Non-alcoholic Fatty Liver Disease: Possible Role for MAPK and NF- $\kappa$ B? Am J Gastroenterol 2016;111:852-63.

9. Fedirko V, Duarte-Salles T, Bamia C, Trichopoulou A, Aleksandrova K, Trichopoulos D, et al. Prediagnostic circulating vitamin D levels and risk of hepatocellular carcinoma in European populations: A nested case-control study. Hepatology 2014;60:1222-30.

10. Green RJ, Samy G, Miqdady MS, El-Hodhod M, Akinyinka OO, Saleh $\mathrm{G}$, et al. Vitamin D deficiency and insufficiency in Africa and the Middle East, despite year-round sunny days. South African Med J 2015;105:603.

11. Mohamed AA, Sabry NA, Abbassi MM, Ibrahim WA, Ali-Eldin ZA. Vitamin D levels in Egyptian HCV patients (genotype 4) treated with pegylated interferon. Acta Gastroenterol Belg 2013;76:38-44.

12. Botros RM, Sabry IM, Abdelbaky RS, Eid YM, Nasr MS, Hendawy LM. Vitamin D deficiency among healthy Egyptian females. Endocrinol y Nutr 2015;62:314-21.

13. Amr N, Hamid A, Sheta M, Elsedfy H. Vitamin D status in healthy Egyptian adolescent girls. Georgian Med News 2012;65-71.

14. Kennel KA, Drake MT, Hurley DL. Vitamin D deficiency in adults: when to test and how to treat. Mayo Clin Proc 2010;85:752-7-8.

15. Konstantakis C, Tselekouni P, Kalafateli M, Triantos C. Vitamin D deficiency in patients with liver cirrhosis. Ann Gastroenterol 2016;29:297306.

16. Hoan NX, Khuyen N, Binh MT, Giang DP, Van Tong H, Hoan PQ, et al. Association of vitamin D deficiency with hepatitis B virus - related liver diseases. BMC Infect Dis 2016; 16:507.

17. Chan HL-Y, Elkhashab M, Trinh H, Tak WY, Ma X, Chuang W-L, et al. Association of baseline vitamin D levels with clinical parameters and treatment outcomes in chronic hepatitis B. J Hepatol 2015;63:1086-92.

How to cite this article: Said E, El Agawy W, Ahmed R, Hassany M, Ahmed $A$, Fouad $H$, et al. Serum vitamin $D$ levels in treatment-naïve chronic hepatitis B patients. J Transl Intern Med 2017; 5: 230-4. 